Journal of Engineering and Applied Sciences 14 (12): 4139-4145, 2019

ISSN: 1816-949X

(C) Medwell Journals, 2019

\title{
The Simulation of Navy Fleet Placement Model using Covering Technique and Binary Matrix Decision Variable
}

\author{
Bambang Suharjo and Okol Sri Suharyo \\ Indonesia Naval Technology College, STTAL Surabaya, Indonesia
}

\begin{abstract}
Maritime security patrol is a presence operation of the sea which has a strategic value for the nation's sovereignty existence and maritime security in the areas of national jurisdiction of a country. Security threats and breaches in the sea in the form of illegal fishing, illegal logging and other natural resources as well as encroachment by Foreign vessels requires the presence of navy patrol ships for security and navy fleet as support. Limited number of navy patrol ships lack of provided by the state budget and the needs of homeland security resulted in the territorial sea need more thinking about optimizing the assignment of patrol ships in the navy operations sector. The placement of the navy fleet take into account the ship type, speed, radar range, sailing abilities (endurance) and human resources, so that, it results the optimization of the assignment composition of some navy patrol ships to the naval operation sectors by maximizing the coverage area and minimizing operational costs. Covering technique method is used to select the navy fleet by minimizing the number of navy fleet which can cover and replace other fleet. The Binary Matrix Decision Variable (BMDV) is the model of the assignment patrol ships and the placement of navy fleet to the naval operation sectors.
\end{abstract}

Key words: Navy fleet, covering technique, binary matrix decision variable, homeland security, maximizing, sailing abilities

\section{INTRODUCTION}

Maritime security patrol is a presence marine operation which has strategic value for the existence of the nation's sovereignty and maritime security in the areas of Indonesian national jurisdiction. Security breaches such as illegal lodging and illegal fishing by Foreign vessel as well as another illegal resource requires patrol ships to secure Indonesian archipelago which has total territory almost reach 3.9 million $\mathrm{km}^{2}$. Indonesian command fleet has the main naval operational command from North-South territorial Indonesian maritime jurisdiction, starting from Java Sea in the Northern of Central Java to East Aru Sea in the Southern of papua and pacific ocean in the Northern of papua and has been doing daily presence operation in the sea. Yet, in terms of the ability of patrol ship and also operation cost associated with the range of the maritime operation sector is still not optimal, so that, it needs to be considered and well calculated in giving a command to the patrol ships to operation sectors. The limited of technical capability and quantity of patrol ships, funds provided by the state and the demand of maritime security on assignment aboard marine areas in the sectors of maritime security operations Eastern region to optimize giving a duty to patrol ships, thus, the proper type, quantity can be used to select the right navy fleet that will be developed as supporting navy fleet in securing operation sector in Eastern sea area (Fig. 1 and Table 1).
Each of navy patrol ship that will be assigned to operation sector has different capabilities such as speed, radar, endurance, distance and coverage area and also operation cost. Determining operation sector for assignment of navy patrol ship is very important case,

\begin{tabular}{|c|c|c|c|}
\hline Ship code & Speed V (Knot) & Radard (Mil) & Endurance $(\mathrm{E})$ (Day) \\
\hline SP & 14 & 50 & 4 \\
\hline AM & 15 & 48 & 3 \\
\hline UK & 12 & 49 & 4 \\
\hline TO & 14 & 51 & 5 \\
\hline IR & 13 & 53 & 4 \\
\hline MS & 14 & 50 & 4 \\
\hline PD & 15 & 48 & 5 \\
\hline BS & 13 & 47 & 3 \\
\hline MB & 15 & 47 & 4 \\
\hline DG & 18 & 49 & 4 \\
\hline RA & 16 & 48 & 5 \\
\hline IU & 17 & 50 & 3 \\
\hline YG & 16 & 46 & 4 \\
\hline $\mathrm{KP}$ & 15 & 44 & 5 \\
\hline RP & 17 & 47 & 3 \\
\hline $\mathrm{KL}$ & 15 & 48 & 5 \\
\hline DK & 18 & 49 & 4 \\
\hline MD & 17 & 50 & 5 \\
\hline LP & 24 & 48 & 3 \\
\hline $\mathrm{TN}$ & 25 & 44 & 4 \\
\hline RK & 26 & 47 & 3 \\
\hline $\mathrm{NN}$ & 23 & 48 & 4 \\
\hline LK & 25 & 49 & 5 \\
\hline $\mathrm{DN}$ & 22 & 50 & 4 \\
\hline TL & 26 & 45 & 3 \\
\hline WS & 24 & 44 & 5 \\
\hline$\underline{\mathrm{LG}}$ & 25 & 48 & 3 \\
\hline
\end{tabular}

Corresponding Author: Bambang Suharjo, Indonesia Naval Technology College, STTAL Surabaya, Indonesia 


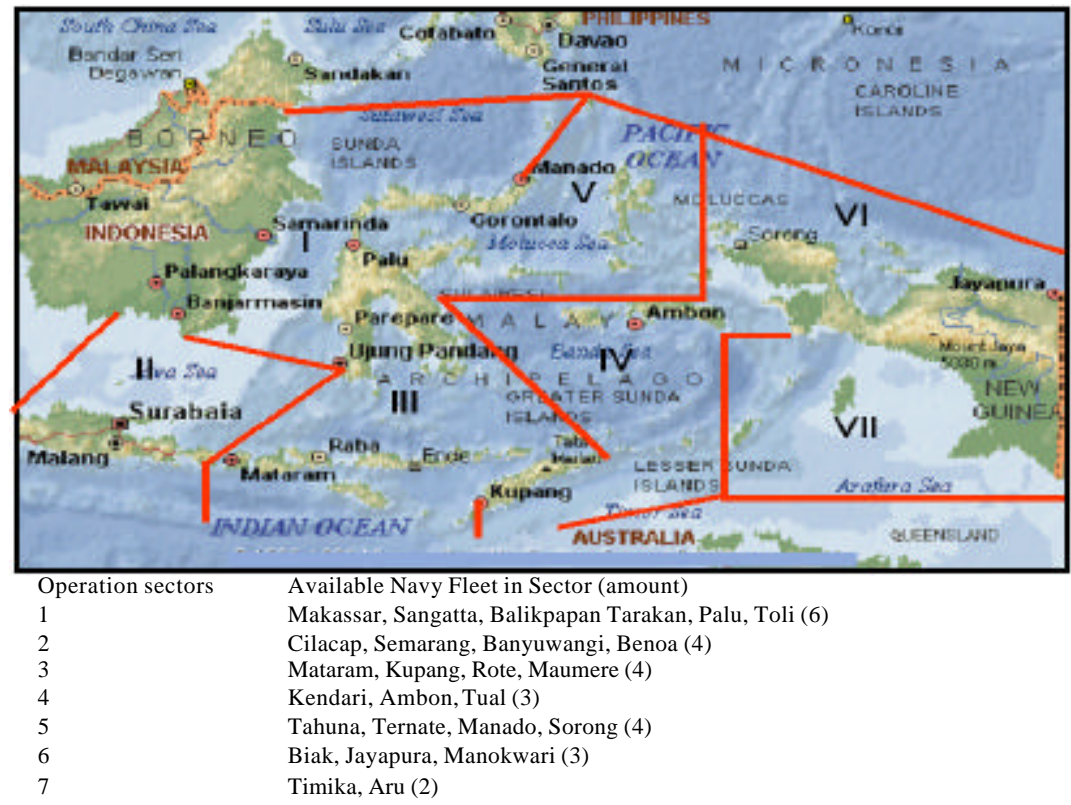

Fig. 1: Navy fleet and naval operation sectors map

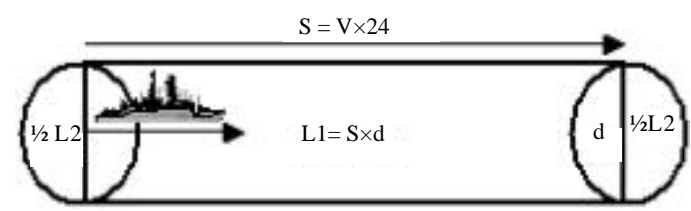

Fig. 2: Wide range of coverage area of patrol ship; OS. Suharyo et al. (2017); ( $\mathrm{S}=$ Cruising distance per day $=$ Velocity $\times 24 \mathrm{~h}(\mathrm{mil}) ; \mathrm{d}=$ Range of radar (Mil); $\mathrm{L} 1=$ Area of rectangle $=\mathrm{S} \times \mathrm{d}\left(\mathrm{Mil}^{2}\right) ; \mathrm{L} 2=$ Area of circle $={ }_{\mathrm{r}} \mathrm{r} 2(\mathrm{Mil} 2) ; \mathrm{CA}=$ Coverage area $=(\mathrm{L} 1+\mathrm{L} 2)$ $=(\mathrm{L} 1+\mathrm{L} 2)(\mathrm{Mil} 2) ; \mathrm{RE}=$ Max cruising distance of patrol ship $=$ Cruising distance per day $\times$ Endurance $=\mathrm{RE}=\mathrm{S} \times \mathrm{E}(\mathrm{mil}))$

based on how to maximize coverage area of navy patrol ship attainment to cover the wide range of operation sector and how to minimize operation cost of patrol ship (Table 1 and Fig. 2).

\section{MATERIALS AND METHODS}

Covering technique: The methods is optimizing navy fleet method having the goal to minimize quantity of hub port/navy fleet which is needed to serve/cover another navy fleet. Selected navy fleet will cover the another navy fleet, thus, it will minimize quantity of navy fleet in case of cost saving because selected navy fleet will be developed as the main navy fleet.

According Sunderesh (1997) covering technique appears in a system that has every customer requirement can be reached by at least one facility. Meanwhile according to Mark (1995) covering technique is how to determine the lowest cost of placement facilities where each demand node can be reached by at least one facility. The second understanding of the above generally, covering technique can be defined as the selection of the alternatives location that exist for the purpose of minimizing the entire factors that influence the restriction that any demand can be reached by the selected location. A region is known having the range area (coverage area) if the area is located at a distance range. The determination of the distance range is very important to note the application of the method of covering technique because it is the most influential factor on resulting optimal solution. The problems of covering technique are placing the facilities in the minimum amount required to cover all locations clicking demand or if in this research selecting and placing navy fleets in the amount planned to cover defense and security sector of the sea. The parameters used in the model form of covering technique are the distance and location of the naval operating sectors formulated to plan the number of navy fleets objective function:

$$
\text { Minimize } \sum_{j \in J}^{n} x_{j}
$$

Subject to the constrain:

$$
\sum_{j \in \mathbb{N}}^{\mathrm{n}} \mathrm{Xi} \geq 1, \mathrm{Xi} \in\{0,1\}
$$

Binary Matrix Decision Variable (BMDV): In this study, the creativity and development of the concepts of covering technique methods is an additional program in 


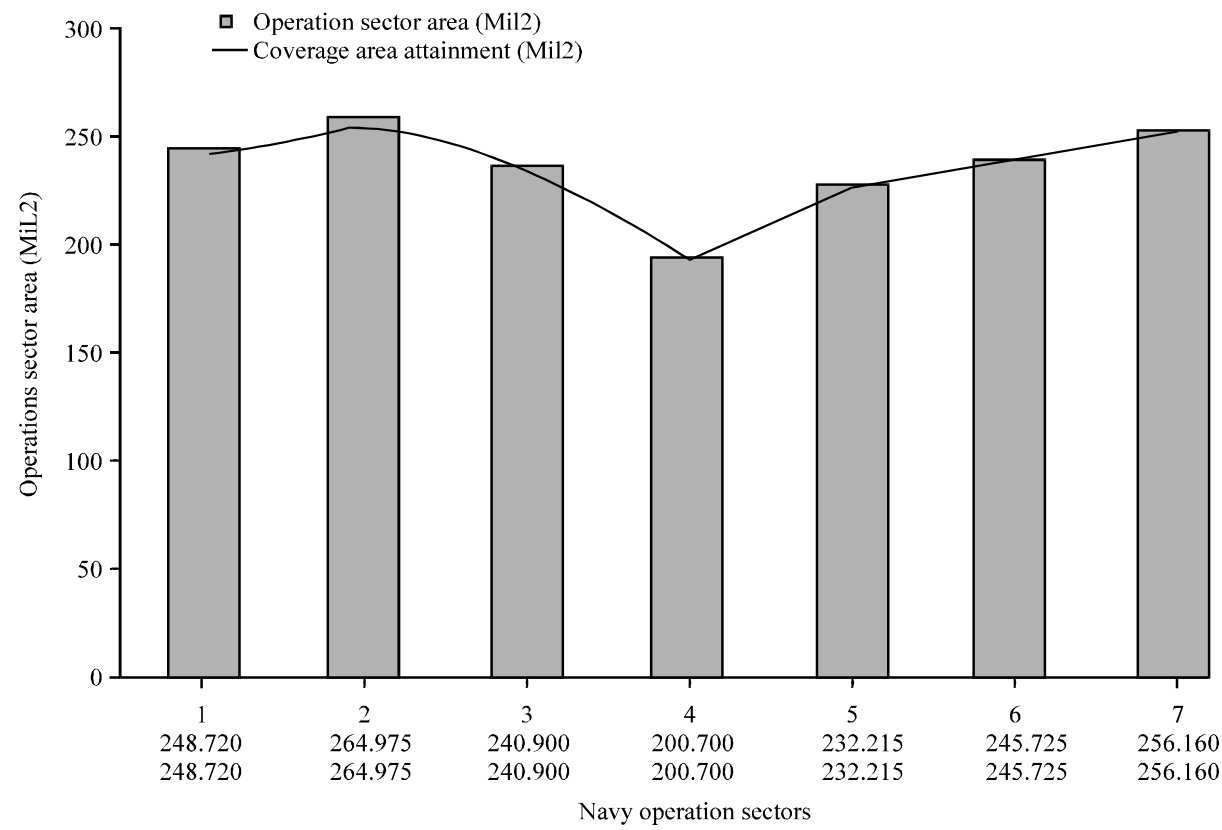

Fig. 3: Coverage area attainment by assignment of patrol ships

\begin{tabular}{|c|c|c|c|c|c|}
\hline \multirow[b]{2}{*}{ Variable (i) } & \multicolumn{5}{|c|}{ Variable $\mathrm{j}$} \\
\hline & $\mathrm{j}-1$ & 1 & 2 & 3 & $j-n$ \\
\hline $\mathrm{i}-1$ & $X 1,1$ & $X 1,2$ & $X 1,3$ & $X 1,4$ & $\mathrm{X} 1, \mathrm{j}$ \\
\hline . & $X 2,1$ & $\times 2,2$ & $\times 2,3$ & $\times 2,4$ & $\times 2, j$ \\
\hline . & $X 3,1$ & $\times 3,2$ & $\times 3,3$ & $\times 3,4$ & $\times 3, j$ \\
\hline . & $X 4,1$ & $\times 4,2$ & $\begin{array}{r}X, 3 \\
\end{array}$ & $\times 4,4$ & $\mathrm{X} 4, \mathrm{j}$ \\
\hline $\mathrm{i}-\mathrm{n}$ & $\mathrm{Xi}, 1$ & $\mathrm{Xi}, 2$ & $\mathrm{Xi}, 3$ & $\mathrm{Xi}, 4$ & $\mathrm{xi}, \mathrm{j}$ \\
\hline
\end{tabular}

the form of Binnet decision variable. Binary matrix is the decision-making variables that have price value of (zero) or (one) (zero) means that the Xij variable is not selected and (one) means that the Xij variable is not selected in Fig. 3. Decision 0 or 1 is an integer instead of fractional decision, since, the assignment of patrol ships and the selection of the navy fleet are the selection of a unity variables intact as a single navy fleet unit (Table 2-4).

\section{The research methodology}

The first step: In this research is determining the ships assignment of 27 navy patrol ships to the 7 navy operation sectors which formulated in the following steps.

Determining the objective function: Maximizing the coverage area that secured by patrol ship:

$$
\operatorname{Max} Z 1=\sum_{\mathrm{i} \in \mathrm{I}}^{\mathrm{n}} \sum_{\mathrm{j} \in \mathrm{J}}^{\mathrm{n}} \mathrm{CAij} . \mathrm{Xij}
$$

\section{Minimizing operation costs:}

$$
\operatorname{Min} Z 2=\sum_{i \in I}^{n} \sum_{j \in J}^{n} C i j . \text { Xij }
$$

\begin{tabular}{|c|c|c|c|c|c|}
\hline \multirow[b]{2}{*}{$\underline{\text { Patrol ships-i }}$} & \multicolumn{5}{|c|}{ Operations sectors- $\mathrm{j}$} \\
\hline & $\mathrm{j}-1$ & 1 & 2 & 3 & $\mathrm{~J}-7$ \\
\hline $\mathrm{i}-1$ & $X 1,1$ & $\mathrm{X} 1,2$ & $X 1,3$ & $X 1,4$ & $\mathrm{X} 1, \mathrm{j}$ \\
\hline . & $X 2,1$ & $X 2,2$ & $\times 2,3$ & $X 2,4$ & $X 2, j$ \\
\hline . & $X 3,1$ & $X 3,2$ & $X 3,3$ & $X 3,4$ & $X 3, \mathrm{j}$ \\
\hline . & $X 4,1$ & $X 4,2$ & $X 4,3$ & $X 4,4$ & $\mathrm{X} 4, \mathrm{j}$ \\
\hline $\mathrm{i}-27$ & $\mathrm{Xi}, 1$ & $\mathrm{Xi}, 2$ & $\mathrm{Xi}, 3$ & $\mathrm{Xi}, 4$ & $\mathrm{xi}, \mathrm{i}$ \\
\hline
\end{tabular}

Table 3: Binery matrix assigned to operation sector-i

$\mathrm{Xij}=$ Patrol ship $\mathrm{i}(1-27)$ assigned to operation sector- $\mathrm{j}(1-7) ; \mathrm{X} \mathrm{ij}=0$ (zero), patrol ship-i isn't assigned to operation sector- $\mathrm{j}$; $\mathrm{Xij}=1$ (one), patrol ship- $\mathrm{i}$ is assigned to operation sector- $\mathrm{j}$

Table 4: "Binary matrix" selection of navy fleet in sectors

\begin{tabular}{|c|c|c|c|c|c|}
\hline \multirow[b]{2}{*}{ Navy fleet-k } & \\
\hline & $\mathrm{i}-1$ & 1 & 2 & 3 & $\mathrm{~J}-7$ \\
\hline i-1 & $\mathrm{X} 1,1$ & $\mathrm{X} 1,2$ & $\mathrm{X} 1,3$ & $\mathrm{X} 1,4$ & $\mathrm{X} 1, \mathrm{j}$ \\
\hline . & $X 2,1$ & $\times 2,2$ & $\times 2,3$ & $\times 2,4$ & $\times 2, \mathrm{j}$ \\
\hline . & $\mathrm{X} 3,1$ & $\times 3,2$ & $\times 3,3$ & $\times 3,4$ & $\mathrm{X} 3, \mathrm{j}$ \\
\hline . & $X 4,1$ & $X 4,2$ & $X 4,3$ & $\times 4,4$ & $\mathrm{X} 4, \mathrm{j}$ \\
\hline $\mathrm{i}-26$ & $\mathrm{Xi}, 1$ & $\mathrm{Xi}, 2$ & $\mathrm{Xi}, 3$ & $\mathrm{Xi}, 4$ & $\mathrm{Xi}, \mathrm{i}$ \\
\hline
\end{tabular}
Operations sectors- $\mathrm{j}$

$\mathrm{X} \mathrm{kj}=0$ (zero), the navy fleet-k is not selected to cover sector- $\mathrm{j}$; $\mathrm{X} \mathrm{kj}=1$ (one), the navy fleet-k is selected to cover sector-j

Where:

CAij = Coverage Area of patrol ship-i (1-27) in operation sector-j (1-7)

$\mathrm{Cij}=$ Operation Costs of patrol ship-i (1-27) in operation sector-j (1-7)

$\mathrm{Xij}=$ Patrol ship-i (1-27) assigned to the operation sector-j (1-7)

Determining constrain: Attainment coverage area of navy patrol ship in sector should be equal to the smaller of the coverage area ability of patrol ship: 


$$
\mathrm{CA} \mathrm{ij} \leq \mathrm{CB} \text { ij }
$$

Where:

$$
\begin{aligned}
\text { CAij }= & \text { Coverage Area attainment of patrol ship-i }(1-27) \\
& \text { in sector- } \mathrm{j}(1-7) \\
\text { CBij }= & \text { Coverage area ability of patrol ship-i }(1-27) \text { in } \\
& \text { operation sector- } \mathrm{j}(1-7)
\end{aligned}
$$

Operation costs of patrol ships not exceeding budget fund's plan:

$$
\text { Cij } \leq \text { Budget cost }
$$

Where:

$$
\begin{aligned}
\mathrm{Cij}= & \text { Operation Costs of patrol ship-i }(1-27) \text { in } \\
& \text { the operation sector- } \mathrm{j}(1-7) \\
\text { Budget cost }= & \text { Budget funds provided }
\end{aligned}
$$

Determining the decision variable: "Binary matrix" assignment of 27 patrol ships to 7 operation sectors:

The second step: The second step of this research is determining further about the selection of navy fleet in the navy operations sector as a base for navy patrol ships. The model can be formulated on the following steps.

Determining of the objective function: Minimizing the number of navy fleet-k to cover more navy fleets in the operation sector-j:

$$
\mathrm{Zmin}=\sum_{\mathrm{k} \in \mathrm{K}}^{\mathrm{n}} \sum_{\mathrm{j} \in \mathrm{J}}^{\mathrm{n}} \mathrm{Xkj} \cdot(\mathrm{Cpb}) \mathrm{kj}
$$

Maximizing the range operation of the patrol ship in navy fleet-k to operation sector-j:

$$
\mathrm{Zmax}=\sum_{\mathrm{k} \in \mathrm{K}}^{\mathrm{n}} \sum_{\mathrm{j} \in J}^{\mathrm{n}} \mathrm{Dkj} \cdot \mathrm{Xkj} \cdot(\mathrm{Cpb}) \mathrm{kj}
$$

Determining constraints function: The distance range of patrol ship operation from navy fleet-k position to operation sector- $\mathrm{j}$ and return to navy fleet-k does not exceed the ability of navy patrol ships cruising distance endurance (RE patrol ship):

$$
\text { Dkj . Xkj } \leq \text { RE patrol ship }
$$

Operation sector-j covered by at least one navy fleet-k:

$$
\mathrm{Xkj} \geq 1
$$

. $\quad \mathrm{Xkj}=$ Navy fleet-k to cover operation sector- $\mathrm{j}$

- $\quad$ Dkj $=$ Range operation of patrol ship in the navy fleet-k to operation sector- $\mathrm{j}$ then subsequently return to navy fleet-k

(Cpb) $\mathrm{kj}=$ Compatibility of navy fleet-k towards operation sector-j

- $\mathrm{RE}=$ Cruising distance of patrol ship in once endurance

Determining decision variables: "Binary matrix" selection of navy fleet in sectors.

Analysis and data processing: Calculation of Coverage area ability (CB) and max cruising distance (RE) in each patrol ship, navy fleet based on the data speed, radar range, Endurance $(\mathrm{E})$ and cruising distance of patrol Ship

\begin{tabular}{|c|c|c|c|}
\hline Ship code & $\mathrm{S}$ (Mil) & $\mathrm{RE}=\mathrm{S}^{*} \mathrm{E}$ (Mil) & CB (Mil/day) \\
\hline SP & 336 & 1.344 & 16.886 \\
\hline $\mathrm{AM}$ & 360 & 1.080 & 17.180 \\
\hline UK & 288 & 1.152 & 14.397 \\
\hline TO & 336 & 1.680 & 17.260 \\
\hline IR & 312 & 1.248 & 16.867 \\
\hline MS & 336 & 1.344 & 16.886 \\
\hline $\mathrm{PD}$ & 360 & 1.800 & 17.180 \\
\hline BS & 312 & 936 & 14.758 \\
\hline MB & 360 & 1.440 & 16.789 \\
\hline DG & 432 & 1.728 & 20.748 \\
\hline RA & 384 & 1.920 & 18.217 \\
\hline IU & 408 & 1.224 & 20.126 \\
\hline YG & 384 & 1.536 & 17.393 \\
\hline $\mathrm{KP}$ & 360 & 1.800 & 15.624 \\
\hline$R P$ & 408 & 1.224 & 18.819 \\
\hline $\mathrm{KL}$ & 360 & 1.800 & 17.180 \\
\hline DK & 432 & 1.728 & 20.748 \\
\hline $\mathrm{MD}$ & 408 & 2.040 & 20.126 \\
\hline LP & 576 & 1.728 & 26.511 \\
\hline $\mathrm{TN}$ & 600 & 2.400 & 25.128 \\
\hline RK & 624 & 1.872 & 27.956 \\
\hline $\mathrm{NN}$ & 552 & 2.208 & 25.474 \\
\hline LK & 600 & 3.000 & 28.156 \\
\hline $\mathrm{DN}$ & 528 & 2.112 & 25.526 \\
\hline TL & 624 & 1.872 & 26.703 \\
\hline WS & 576 & 2.880 & 24.177 \\
\hline LG & 600 & 1.800 & 27.548 \\
\hline
\end{tabular}
(S) (Table 5). Calculation of patrol ship operation Costs (C), navy fleets on data, Liquid Logistics Costs (LLC: fuel, water, oil) and Personnel Logistics Costs (PLC: meal allowance and crew salary) to carry out the operation (Table 4).

Operation sector of navy fleet data including: The number of navy fleets in each operation sector, Route's length and sector area which is secured (Table 6-8). The optimization process is done using the methodology of this study. The results obtained binary matrix assignment of patrol ships and binary matrix election navy fleet such as Table 8-10. 
Table 6: Operation cost

\begin{tabular}{lccc}
\hline Ship code & LLC/day & PLC/day & Operation Cost (C) \\
\hline SP & 53.140 .350 & 1.755 .000 & 54.595 .350 \\
AM & 54.465 .200 & 1.755 .000 & 55.920 .200 \\
UK & 52.690 .350 & 1.655 .000 & 54.045 .350 \\
TO & 53.605 .200 & 1.655 .000 & 54.960 .200 \\
IR & 53.425 .050 & 1.755 .000 & 54.880 .050 \\
MS & 53.244 .900 & 1.755 .000 & 54.699 .900 \\
PD & 51.885 .200 & 1.555 .000 & 53.140 .200 \\
BS & 52.045 .350 & 1.555 .000 & 53.300 .350 \\
MB & 53.125 .500 & 1.695 .000 & 54.520 .500 \\
DG & 44.030 .950 & 1.339 .000 & 44.994 .950 \\
RA & 44.641 .100 & 1.339 .000 & 45.605 .100 \\
IU & 44.861 .250 & 1.299 .000 & 45.785 .250 \\
YG & 44.236 .250 & 1.299 .000 & 45.160 .250 \\
KP & 44.441 .550 & 1.295 .000 & 45.325 .550 \\
RP & 44.846 .400 & 1.279 .000 & 45.750 .400 \\
KL & 45.790 .950 & 1.295 .000 & 46.674 .950 \\
DK & 46.146 .100 & 1.319 .000 & 47.090 .100 \\
MD & 44.346 .700 & 1.239 .000 & 45.210 .700 \\
LP & 36.804 .300 & 693.333 & 37.297 .633 \\
TN & 37.229 .150 & 673.333 & 37.702 .483 \\
RK & 38.144 .000 & 673.333 & 38.617 .333 \\
NN & 36.789 .450 & 693.333 & 37.282 .783 \\
LK & 37.424 .750 & 693.333 & 37.918 .083 \\
DN & 36.569 .900 & 693.333 & 37.063 .233 \\
TL & 36.050 .200 & 653.333 & 36.503 .533 \\
WS & 35.440 .050 & 653.333 & 35.893 .383 \\
LG & 34.659 .450 & 513.333 & 35.172 .783 \\
\hline
\end{tabular}

Table 7: Operation sector data

\begin{tabular}{lccc}
$\begin{array}{l}\text { Operation } \\
\text { sectors }\end{array}$ & $\begin{array}{c}\text { No. of } \\
\text { navy fleets }\end{array}$ & $\begin{array}{c}\text { Sector area } \\
\text { (Mil) }\end{array}$ & $\begin{array}{c}\text { Route's length } \\
\text { (Mil) }\end{array}$ \\
\hline 1 & 6 & 248.720 & 1.650 \\
2 & 5 & 264.975 & 1.370 \\
3 & 4 & 240.900 & 1.610 \\
4 & 3 & 200.070 & 1.680 \\
5 & 4 & 232.215 & 1.720 \\
6 & 3 & 245.725 & 1.780 \\
7 & 3 & 256.160 & 1.750 \\
\hline
\end{tabular}

Table 8: Binary matrix decision variable "Ships assigment" Decision variable of patrol ships assigment

Operation sectors ( $\mathrm{j})$

\begin{tabular}{llllllll} 
Ships (i) & 1 & 2 & 3 & 4 & 5 & 6 & 7 \\
\hline SP & 0 & 0 & 0 & 0 & 0 & 0 & 1 \\
AM & 0 & 0 & 0 & 1 & 0 & 0 & 0 \\
UK & 0 & 0 & 0 & 0 & 0 & 0 & 1 \\
TO & 0 & 0 & 0 & 0 & 0 & 0 & 1 \\
IR & 0 & 0 & 0 & 0 & 0 & 1 & 0 \\
MS & 0 & 0 & 0 & 0 & 1 & 0 & 0 \\
PD & 0 & 0 & 0 & 0 & 1 & 0 & 0 \\
BS & 0 & 0 & 0 & 0 & 0 & 1 & 0 \\
MB & 0 & 0 & 0 & 1 & 0 & 0 & 0 \\
DG & 1 & 0 & 0 & 0 & 0 & 0 & 0 \\
RA & 1 & 0 & 0 & 0 & 0 & 0 & 0 \\
IU & 0 & 0 & 0 & 0 & 0 & 1 & 0 \\
YG & 0 & 1 & 0 & 0 & 0 & 0 & 0 \\
KP & 0 & 0 & 1 & 0 & 0 & 0 & 0 \\
RP & 0 & 0 & 1 & 0 & 0 & 0 & 0 \\
KL & 1 & 0 & 0 & 0 & 0 & 0 & 0 \\
DK & 0 & 0 & 1 & 0 & 0 & 0 & 0 \\
MD & 0 & 1 & 0 & 0 & 0 & 0 & 0 \\
LP & 0 & 0 & 0 & 0 & 1 & 0 & 0 \\
TN & 0 & 0 & 0 & 0 & 0 & 0 & 0 \\
RK & 0 & 0 & 0 & 0 & 0 & 0 & 0 \\
NN & 0 & 1 & 0 & 0 & 0 & 0 & 0 \\
\hline & & & & & & &
\end{tabular}

Table 8: Continue

Decision variable of patrol ships assigment

Operation sectors (j)

\begin{tabular}{llllllll} 
Ships (i) & 1 & 2 & 3 & 4 & 5 & 6 & 7 \\
\hline LK & 0 & 0 & 0 & 0 & 0 & 0 & 0 \\
DN & 0 & 1 & 0 & 0 & 0 & 0 & 0 \\
TL & 0 & 0 & 0 & 0 & 0 & 0 & 0 \\
WS & 0 & 0 & 0 & 0 & 0 & 0 & 0 \\
LG & 0 & 0 & 0 & 0 & 0 & 0 & 0 \\
\hline
\end{tabular}

$\mathrm{X} \mathrm{ij}=0$, patrol ship-i isn't assigned to operation sector- $\mathrm{j} ; \mathrm{X} \mathrm{ij}=1$,

patrol ship-i is assigned to operation sector- $\mathrm{j}$

Table 9: Assignment of navy patrol ships to the operation sectors

Patrol ship Ops Total attainment of Total attainment of assignment (Amount) sectors coverage area (Mil) cost (Idr)

$\begin{array}{llll}\text { DG, RA, KL (3) } & 1 & 248.720 & 1.615 .976 .388\end{array}$

YG, MD, NN, DN (4) $\quad 2 \quad 264.975 \quad 1.501 .669 .737$

KP, RP, DK (3) $\quad 3 \quad 240.900 \quad 1.610 .180 .784$

$\begin{array}{llll}\mathrm{UK}, \mathrm{MB}(2) & 4 & 200.070 & 1.499 .715 .843\end{array}$

MS, PD, LP (3) $\quad 5 \quad 232.215 \quad 1.637 .369 .820$

$\begin{array}{llll}\text { IR, BS, IU (3) } & 6 & 245.725 & 1.797 .415 .784\end{array}$

SP, AM, TO (3) $\quad 7 \quad 256.160 \quad 1.868 .690 .615$

Table 10: Binary matrix decisiom variable "Selection of navy fleet" Decision variable of navy fleet selection

Operation sector (j)

\begin{tabular}{|c|c|c|c|c|c|c|c|}
\hline \multirow[b]{2}{*}{ Navy fleet (k) } & & & & & & & \\
\hline & 1 & 2 & 3 & 4 & 5 & 6 & 7 \\
\hline Cilacap & 0 & 0 & 0 & 0 & 0 & 0 & 0 \\
\hline Semarang & 0 & 0 & 0 & 0 & 0 & 0 & 0 \\
\hline Surabaya & 0 & 1 & 0 & 0 & 0 & 0 & 0 \\
\hline Banyuwangi & 0 & 0 & 0 & 0 & 0 & 0 & 0 \\
\hline Benoa & 0 & 0 & 0 & 0 & 0 & 0 & 0 \\
\hline Makassar & 1 & 0 & 0 & 0 & 0 & 0 & 0 \\
\hline Sangatta & 1 & 0 & 0 & 0 & 0 & 0 & 0 \\
\hline Balikpapan & 0 & 0 & 0 & 0 & 0 & 0 & 0 \\
\hline Tarakan & 0 & 0 & 0 & 0 & 0 & 0 & 0 \\
\hline Palu & 0 & 0 & 0 & 0 & 0 & 0 & 0 \\
\hline Toli-Toli & 0 & 0 & 0 & 0 & 0 & 0 & 0 \\
\hline Tahuna & 0 & 0 & 0 & 0 & 0 & 0 & 0 \\
\hline Mataram & 0 & 0 & 0 & 0 & 0 & 0 & 0 \\
\hline Kupang & 0 & 0 & 0 & 0 & 0 & 0 & 0 \\
\hline Rote & 0 & 0 & 0 & 0 & 0 & 0 & 0 \\
\hline Maumere & 0 & 0 & 1 & 0 & 0 & 0 & 0 \\
\hline Kendari & 0 & 0 & 0 & 0 & 0 & 0 & 0 \\
\hline Ambon & 0 & 0 & 0 & 1 & 0 & 0 & 0 \\
\hline Tual & 0 & 0 & 0 & 0 & 0 & 0 & 0 \\
\hline Ternate & 0 & 0 & 0 & 0 & 1 & 0 & 0 \\
\hline Manado & 0 & 0 & 0 & 0 & 0 & 0 & 0 \\
\hline Sorong & 0 & 0 & 0 & 0 & 0 & 0 & 0 \\
\hline Biak & 0 & 0 & 0 & 0 & 0 & 0 & 0 \\
\hline Jayapura & 0 & 0 & 0 & 0 & 0 & 0 & 0 \\
\hline Manokwari & 0 & 0 & 0 & 0 & 0 & 1 & 0 \\
\hline Timika & 0 & 0 & 0 & 0 & 0 & 0 & 0 \\
\hline Aru & 0 & 0 & 0 & 0 & 0 & 0 & 1 \\
\hline Merauke & 0 & 0 & 0 & 0 & 0 & 0 & 0 \\
\hline
\end{tabular}

Significants bold values; $\mathrm{X} \mathrm{kj}=0$, the navy fleet-k is not selected to cover sector $-\mathrm{j} ; \mathrm{X} \mathrm{kj}=1$, the navy fleet- $\mathrm{k}$ is selected to cover sector- $\mathrm{j}$

\section{RESULTS AND DISCUSSION}

In general research, the placement about a location has a lot to do. Methods for site placement have also 
been widely applied and developed. Some researchers who have done Asgari et al. (2007) conducts optimized selection of military logistic warehouse site by joining covering technique design and $\mathrm{MCDM}$ with various variable such as climate, geology, military factors, economy and infrastructure. Jia et al. (2007) optimizing the selection of the location of medical supplies facilities with maximal covering methods and Genetic problems algorithm. Shourijeh et al. (2012) in his research on the optimization of placements where telecenters by using the method of mathematical optimization models combined with multi objective Optimization Problem (MOP) goal programming. Pal and Kumar (2013) conducted a wind turbine site selection optimization with fuzzy logic and GIS system uses 3 parameters that are qualitative environmental conditions, location and the physical condition of the human factor. Different with the other, the proposed methodology in the study is a development of the theory of sets covering concept introduced by Mark (1995) and Sunderesh (1997). The set covering methodology followed up by Manfaat (1998) in study about computer-based approach to the effective utilization of spatial layout design experience and the next done by Suharyo et al. (2017) developed a set covering theory as part of the navy fleet placement. The creativity and development of the methods concepts mentioned above is the additional program in the form of zero-one matrix of decision variable in theoretical concept of covering technique. Zero-one matrix is the decision-making variable that has price value of 0 or 1.0 (zero) means that the patrol ships or navy fleet is not elected and 1 means that the patrol ships or navy fleet is selected to cover in the operations sectors. The results are considered as the most optimum compromised objective function by maximizing coverage area and minimizing operation costs.

Selected patrol ships to cover sector 1 are DG, RA KL with makassar and sangatta fleet locations, sector 2 is covered by $\mathrm{YG}, \mathrm{MD}, \mathrm{NN}$, DN ships with Surabaya fleet location, sector 3 is covered by KP, RP, DK with maumere fleet location, sector 4 is covered by UK, MB with Ambon fleet location, sector 5 is covered by MS, PD, LP with Ternate fleet location, sector 6 is covered by IR, BS, IU with Manokwari fleet location and sector 7 is covered by SP, AM, TO with Aru fleet location. The selected navy fleets cover the operation sector with its strategic position to reach the location of the operation sector can be reached by patrol ships which assigned to the operation sector without re provision in any other navy fleet maximum cruising range patrol ship able to reach the area in the operation sector (Fig. 3).

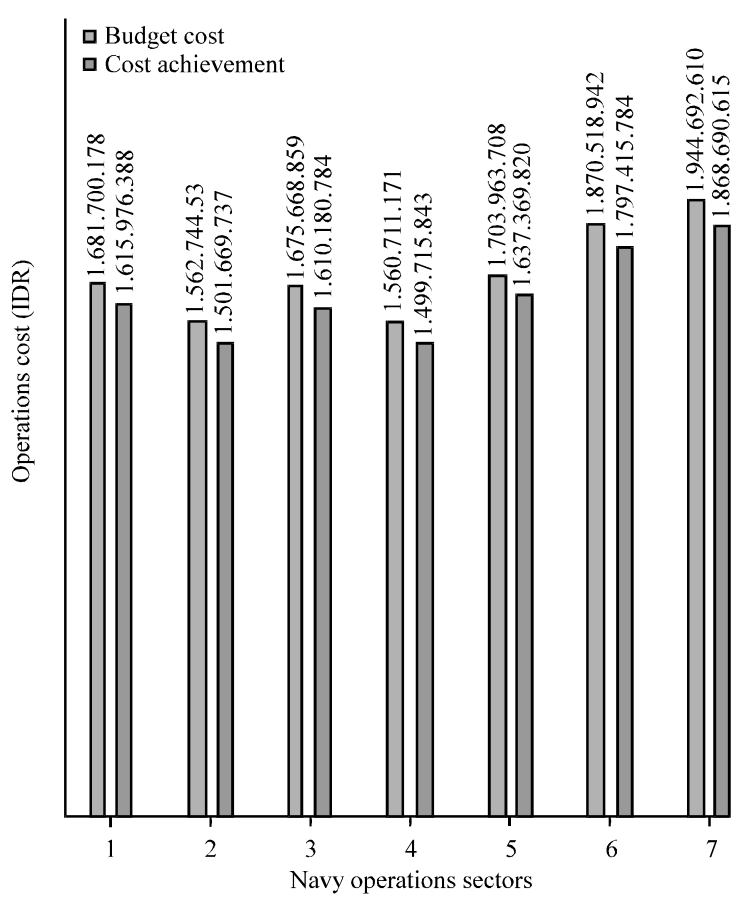

Fig. 4: Operation cost attainment by assignment of patrol ships

Maximum total of coverage area attainment is secured by patrol ship in all sectors mounted to 1.688 .765 Mil2. While the entire wide operation sector 1-7 are of 1.688 .765 Mil2, its mean all of sector's area can be covered by patrol ship within the optimization results of patrol ship's composition in Fig. 4. The total operational cost is 11.531.018.970. It does not exceed the budget cost (12.000.000.000) and there are efficiency of $3.9 \%$ budget see detail in Fig. 4. The results are considered as the most optimum compromised objective function by maximizing coverage area and minimizing operation costs.

\section{CONCLUSION}

In this study, a simulation about navy fleet placement was done. The 2 main problems in this study are how to determine the assigment of 27 navy patrol ships to the 7 operations sector and how to select navy fleet in the navy operations sector as a base for navy patrol ships. The assignment of navy patrol ships to the operations sector is based on the maximum of attainment coverage area purpose and the minimum cost purpose. The selection of navy fleet in operations sector is based on the distance of cruising ship, the distance between navy fleets and the distance of navy fleet to operation sector. The selected navy fleet in this stage must be able to cover the other navy fleet.

In this study, we presented an integration of covering technique methods and binary matrix decision variable. 
The benefits of integration of the 2 methods in this study is indeed simplification of solving problems in the field because the assigment of navy patrol ships and the selection of navy fleet are complex problems. Various variables are very influential in decision-making. Integration of covering technique method and binary matrix decision variable is able to solve these problems very simply and systematically. Based on the experiences gained during this case study, following researches are proposed.

The political and sustainable aspects of the navy fleet as a system needs to be included in the future research as variables in determining of the navy fleet placement beside technical and economic aspects. The political and sustainable aspect of the navy fleet are region vulnerability, border violation, sea crime and society conflict. The sustainable aspect of the navy fleet is assessed on the dynamics of system that happens to any given period of time based on current developments of a political situation (Followed up by researcher on the future research).

\section{ACKNOWLEDGEMENTS}

The researchers greatly acknowledge the support from Indonesian Naval Technology College STTAL for providing necessary resources to carry out this research. The researchers are also grateful to the anonymous reviewers and journal editorial board for their many insightful comments which have significantly improved this study.

This study is the result of the researcher research for the purposes of education only and development of simulation and modeling science not a result of the policy of the Indonesian Navy Institution because the data used is confidential and is used for educational purposes only without reducing the substance of modeling and study interests.

\section{REFERENCES}

Asgari, N., 2007. Combination of MCDM and covering techniques in a hierarchical model for facility location: A case study. Eur. J. Oper. Res., 176: 1839-1858.

Jia, H., F. Ordonez and M.M. Dessouky, 2007. Solution approaches for facility location of medical supplies for large-scale emergencies. Comput. Ind. Eng., 52: 257-276.

Manfaat, D., 1998. Computer-Based Approach to the Effective Utilisation of Spatial Layout Design Experience. The University of Strathclyde, Glasgow, UK.,.

Mark, S.D., 1995. Network and Discrete Location: Models, Algorithms and Applications. Wiley Publishing Company, Hoboken, New Jersey, USA., ISBN:9780471018971, Pages: 498.

Pal, B.B. and M. Kumar, 2013. A linear fuzzy goal programming method for solving optimal power generation and dispatch problem. Intl. J. Adv. Comput. Res., 3: 56-64.

Shourijeh, M.T., M. Kermanshah, A.R. Mamdoohi, A. Faghri and K. Hamad, 2012. A mathematical optimization model for locating telecenters. Appl. Math., 3: 251-263.

Suharyo O.S., D. Manfaat and H.D. Armono, 2017. Establishing the location of naval base using fuzzy MCDM and covering technique methods: A case study. Intl. J. Oper. Quant. Manage., 23: $61-87$.

Sunderesh, S.H., 1997. Facilities Design. PWS Publishing Company, Boston, Massachusetts, USA., ISBN:9780534951832, Pages: 656. 